Cita: Ornelas, F.; Batista, D. R.; Meneghel, V.; Dias, W. G.; Businari, G. B.; Moreno, M. A.; Lopes, C. R.; Braz, T. V. (2020). Exercise intensity to maximal aerobic speed, physical activity level and heart rate variability in postmenopausal women. Cuadernos de Psicología del Deporte, 20(2), 63-70

\title{
Exercise intensity to maximal aerobic speed, physical activity level and heart rate variability in postmenopausal women
}

\section{Intensidad del ejercicio para la velocidad aeróbica máxima, nivel de actividad física y variabilidad de la frecuencia cardíaca en mujeres posmenopáusicas}

\section{Intensidade do exercício para velocidade aeróbica máxima, nível de atividade física e variabilidade da frequência cardíaca em mulheres na pós-menopausa}

\author{
Ornelas, F.1,2; Batista, D. R.1; Meneghel, V.2; Dias, W. G.1; Businari, G. B.1; Moreno, M. A.1; Lopes, C. \\ R.1; Braz, T. V1,2.
} 1Methodist University of Piracicaba - Brazil/SP; 2 Faculty of Americana - Brazil/SP

\begin{abstract}
Physical inactivity is main cause of disease worldwide. Identify the physical exercise preference, resulting in increases adherence and future intention to perform physical activity. The preference of the intensity of exercise questionnaire (PRETIE-Q) is the main tool used to assess preference in physical exercise. Variables as age, body mass index (BMI), usual physical activity level (PAL), maximal oxygen uptake (VO2máx), can influence in PRETIE$\mathrm{Q}$ answers. The purpose of this study was investigate if there is relation between preference for exercise intensity with maximal aerobic speed (MAS), PAL and heart rate variability (HRV) in postmenopausal women phase. Participated of study 30 subjects who answer PRETIE-Q together with analyses of MAS, PAL and HRV. Preference was large correlated with MAS $(r=0.63)$, PAL $(r=0.57)$ and HRV RMSSD $(r=0.52)$. Together, MAS $(40.4 \%)$, PAL (10.7\%) and HRVRMSSD (6.4\%) explained $57.5 \%$ of the preference score. This results study allow to health professional, that prescribe physical exercise, understand that subjects with high aerobic capacity, cardiovagal modulation and usual PAL will have preference for high intensity exercise. In consequence, can increase the adherence to systematic practice of physical exercise. Conclude that preference of exercise intensity for women in postmenopausal phase is related with aerobic capacity, high HRV and physical activity level.
\end{abstract}

Keywords: Preference, aerobic capacity, autonomic nervous system, physical activity level. 


\section{Ornelas, Batista, Meneghel, Dias, Businari, Moreno, \& Lopes, Braz}

\section{RESUMEN}

La inactividad física es la principal causa de enfermedades en todo el mundo. Identificar la preferencia al ejercicio físico da como resultado una mayor adherencia y una futura intención de realizar actividad física. El cuestionario de preferencia para al ejercicio físico (PRETIE-Q) es la herramienta principal utilizada para evaluar la preferencia en el ejercicio físico. Las variables como la edad, el índice de masa corporal (IMC), el nivel de actividad física habitual (NAFH), la captación máxima de oxígeno (VO2max) pueden influir en las respuestas de PRETIE-Q. El objetivo de este estudio fue investigar si existe una relación entre la preferencia por la intensidad del ejercicio y la velocidad aeróbica máxima (VAM), la NAFH y la variabilidad de la frecuencia cardíaca (VFC) en mujeres posmenopáusicas. El estudio incluyó a 30 individuos que respondieron a PRETIE-Q junto con análisis de VAM, NAFH y HRV. La preferencia tenía una gran correlación con VAM $(r=0.63)$, NAFH $(r=0.57)$ y VFCRMSSD $(r=0.52)$. VAM $(40,4 \%)$, NAFH $(10,7 \%)$ y VFC RMSSD $(6,4 \%)$ juntos explican el 57,5\% de la preferencia del resultado. Los resultados de este estudio permiten que los profesionales de la salud, que prescriben el ejercicio físico, comprendan que las personas con alta capacidad aeróbica, la modulación cardiovagal y la NAFH tendrán preferencia por el ejercicio de alta intensidad. En consecuencia, puede aumentar la adherencia a la práctica sistemática del ejercicio físico. Se concluye que la preferencia de intensidad de ejercicio para las mujeres posmenopáusicas está relacionada con la capacidad aeróbica, alta VFC y nivel de actividad física.

Palabras clave: preferencia, capacidad aeróbica, sistema nervioso autonómico, nivel de actividad física.

\section{RESUMO}

Inatividade física é a principal causa de doenças ao redor do mundo. Identificar a preferência ao exercício físico, resulta em aumento da aderência e intenção futura para realizar a atividade física. O questionário de preferência do exercício físico (PRETIE-Q) é a principal ferramenta usada para avaliar preferência em exercício físico. Variáveis como idade, índice de massa corporal (IMC), nível de atividade física habitual (NAFH), consumo máximo de oxigênio (VO2máx), podem influenciar nas respostas do PRETIE-Q. O objetivo deste presente estudo foi investigar se existe relação entre preferência pela intensidade do exercício com a velocidade aeróbia máxima (VAM), NAFH, e variabilidade da frequência cardíaca (VFC) em mulheres na fase de pós-menopausa. Participaram do estudo 30 indivíduas que responderam PRETIE-Q junto com análises de VAM, NAFH, e VFC. A preferência teve grande correlação com VAM ( $\mathrm{r}=0.63)$, NAFH $(\mathrm{r}=0.57)$ e VFCRMSSD $(\mathrm{r}=0.52)$. A VAM $(40,4 \%)$, NAFH $(10,7 \%)$, e VFCRMSSD $(6,4 \%)$ juntos explicam 57,5\% da preferência do resultado. Os resultados deste estudo permitem profissionais de saúde, que prescrevem exercício físico, entender que indivíduos com alta capacidade aeróbia, modulação cardiovagal e NAFH terão preferência por exercício de alta intensidade. Em consequência, pode aumentar a aderência para a prática sistemática de exercício físico. Conclui-se que preferência da intensidade de exercício para mulheres em fase pós-menopausa está relacionada com capacidade aeróbia, alta VFC e nível de atividade física.

Palavras chave: preferência, capacidade aeróbia, sistema nervoso autônomo, nível de atividade física. 


\section{Exercise intensity in postmenopausal women}

\section{INTRODUCTION}

Physical inactivity is main cause of disease worldwide, such as obesity, diabetes mellitus type 2 and cardiovascular disease. Recently, considerable progress has been reached, but is considerable failure with measurable impact on global public health due the findings no translated to behavior-changes interventions (Ekkekakis, 2017). Despite interesting strategy to promote cardiovascular health to reduce ratio of cardiac events (Huffman et al., 2013). Pain, sense of exhaustion, displeasure and discomfort are barriers for regular physical activity practice in subjects with low fitness level (Ekkekakis, Hall, \& Petruzzello, 2008).

Self-select exercise can be a good strategy to increase a regular physical activity practice (Ekkekakis, Hall, $\&$ Petruzzello, 2005), since recent researches has observed high effectiveness when environment (Krinski et al., 2017) and intensity (Focht et al., 2015) are self-selected to training. Therefore, researchers can invest time and effort to investigates what are the training methods more pleasant for individuals (Ekkekakis, 2017).

The American College Sports Medicine (ACSM) considers it important to identify the physical exercise preference, resulting in increases adherence and future intention to perform physical activity (Riebe et al., 2015). The main tool to used is the preference of the intensity of exercise questionnaire (PRETIE-Q) (Ekkekakis, Lind, Hall, \& Petruzzello, 2007). However, age, body mass index (BMI), usual physical activity level (PAL), maximal oxygen uptake (VO2máx), are variables that can influence in PRETIE-Q answers (Hall et.al., 2014). Heart rate index, such as heart rate variability (HRV), are influenced by subject characteristics and habits and is directly related to a health condition (Aubert, Seps, \& Beckers, 2003; Billman, 2011).

The literature has not explored this possible relationship in postmenopausal women. Nevertheless, no one knows if the PAL and HRV can influence the preference by intensity exercise, what could be important to increase adherence of this population in systematic practice of exercise. So, the purpose of this study was investigate if there is relation between preference for exercise intensity with maximal aerobic speed (MAS), PAL and HRV in postmenopausal women phase. Such as hypothesis of this study, it is expected that MAS, PAL and HRV are correlated with preference by higher intensity of exercise.

\section{MATERIALS AND METHODS}

\section{Experimental design}

A clinical trial was carried out including 3 sessions at the study site: (a) initial screening, body composition assessment, incremental walk test (ISWT) and familiarization session; (b) $20 \mathrm{~min}$ self-selected session; (c) $20 \mathrm{~min}$ prescribed session. Before the beginning of the sessions, HRV was checked and recorded for $10 \mathrm{~min}$ in the supine position. The subjects were instructed on the procedures, methodologies and differences between self-selected and prescribed sessions before familiarization, where the participants became familiar with the route, scales and the procedures of individual walking pace. In the self-selected exercise session, it was allowed to select the intensity of the exercise. On the third visit, the prescribed session was carried out in the same way as the self-selected session. The variables were recorded during and after exercise sessions. The session site was covered and well ventilated, with the same temperature and humidity in both sessions. There was an interval of 48 hours between the tests. Physical activity levels were classified using the pedometer over the 3 days (Batista et al., 2019).

\section{Participants}

Thirty postmenopausal women were selected to participate in the study, women were already participating in a group in the city of Americana - São Paulo - Brazil, which performed physical activity at least twice a week, the selection of this sample was for convenience $(59.3 \pm 6.1$ years, $64.5 \pm 9.8 \mathrm{~kg}, 158 \pm 7$ $\mathrm{cm}, \mathrm{BMI}=25.7 \pm 3.1 \mathrm{~kg} / \mathrm{m} 2$, Body fat $26.6 \pm 9.1 \%$ ). The Participants were classified as active according to usual PAL rated by pedometer $(9366.37 \pm 3440.79$ steps) (Thompson, Rakow, \& Perdue, 2004). All subjects were healthy and non-smokers. None of the subjects regularly consumed any substance that influenced control tests or currently undergoing hormone replacement therapy. 


\section{Ornelas, Batista, Meneghel, Dias, Businari, Moreno, \& Lopes, Braz}

\section{Instruments}

PRETIE-Q - Preference for and tolerance of the intensity of exercise questionnaire.

The PRETIE-Q was answered in first day, for this study was used only the preference scale, each item following a scale response of five points. The Preference scale contains four items to measure preference by high intensity (items 6, 10, 14, 16) and four to measure preference by low intensity (items 2 , $4,8,12)$. Therefore, the possible total score in each scale has a range of 8 to 40 (Smirmaul et. al., 2015) (Figure 1). Were used the weighted average to define a preference for high intensity and preference for low intensity, being considered above 24 points highintensity end below of 24 points a low intensity.

Por favor, leia cada uma das afirmações seguintes e então utilize a escala de respostas abaixo para indicar se você concorda ou discorda delas. Não há respostas certas ou erradas. Responda rapidamente e assinale a resposta que melhor descreve o que vocè acredita e como você se sente. Certifique-se de responder todas as questões.

\section{1= Discondo totalmente $2=$ Discerdo $3=$ Nem concordonen discordo $4=$ Concordo $5=$ Concordototalmente}

1. Sentir-me cansado durante um exercicio é meu sinal para diminuir ou parar. $\begin{array}{llllll}1 & 2 & 3 & 4 & 5\end{array}$ 2. Eu prefiro me exercitar em baixos niveis de intensidade por uma longa $1 \begin{array}{llllll}1 & 2 & 3 & 4 & 5\end{array}$ duração do que em altos niveis de intensidade por uma curta duração.

3. Durante o exercício, se meus músculos começam a queimar excessiva- $\begin{array}{ccccc}1 & 2 & 3 & 4 & 5\end{array}$ mente ou se eu percebo que estou respirando com muito esforço, é hora

de diminuir.

4. Eu prefiro ir devagar durante meu exercicio, mesmo que isso signifique $\begin{array}{llllll}1 & 2 & 3 & 4 & 5\end{array}$ levar mais tempo.

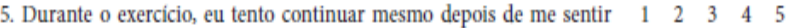
exausto(a).

6. Eu prefiro realizar um exercício curto e intenso, do que um exercicio $1 \begin{array}{lllll}1 & 2 & 3 & 4 & 5\end{array}$ longo e de baixa intensidade.

7. Eu bloqueio a sensação de fadiga quando me exercito. $\quad \begin{array}{lllll}1 & 2 & 3 & 4 & 5\end{array}$

8. Quando me exercito, eu geralmente prefiro um ritmo lento e constante. $1 \begin{array}{lllll}1 & 2 & 3 & 4 & 5\end{array}$

9. Eu prefiro diminuir ou parar quando um exercício começa a ficar muito $\begin{array}{llllll}1 & 2 & 3 & 4 & 5\end{array}$ dificil.

10. Exercitar-me em baixa intensidade não me agrada nem um pouco. $\quad \begin{array}{llllll}1 & 2 & 3 & 4 & 5\end{array}$ 11. Fadiga é a última coisa que me influencia a parar um exercicio; eu tenho $1 \begin{array}{llllll}1 & 2 & 3 & 4 & 5\end{array}$ uma meta e paro somente quando a alcanço.

12. Quando me exercito, eu prefiro atividades que são de ritmo lento e que $\begin{array}{llllll}1 & 2 & 3 & 4 & 5\end{array}$ não requerem muito esforço.

13. Quando meus músculos começam a queimar durante um exercicio, eu $\begin{array}{llllll}1 & 2 & 3 & 4 & 5\end{array}$ geralmente diminuo o ritmo.

14. Quanto mais rápido e dificil for o exercício, mais prazer eu sinto.

15. Eu sempre continuo a me exercitar, apesar da dor muscular e fadiga.

$\begin{array}{lllll}1 & 2 & 3 & 4 & 5\end{array}$

16. Exercicio de baixa intensidade é entediante.

$\begin{array}{lllll}1 & 2 & 3 & 4 & 5\end{array}$

$\begin{array}{lllll}1 & 2 & 3 & 4 & 5\end{array}$

Figure 1. PRETIE-Q - Preference for and tolerance of the intensity of exercise questionnaire.

\section{MAS - Maximal aerobic speed}

For determinate MAS was performed the incremental shuttle walking test (ISWT) in a place marked by cones and length $10 \mathrm{~m}$. The initial cadence of $0.5 \mathrm{~m} \cdot \mathrm{s}-$
1 was increased by $0.17 \mathrm{~m} \cdot \mathrm{s}-1$ every minute until the test was interrupted. The speed was controlled by a sequence of beeps emitted by the Beat Training \& Test ${ }^{\circledR}$ (CEFISE, Nova Odessa, Brazil). The test was finished when subject reached exhaustion volunteer. However they were advised to signal any kind of discomfort and that the test could be interrupted at any time or when they did not reach the minimum distance of $0.5 \mathrm{~m}$ of the cone at the time of the sound stimulus two consecutives stages. Since the protocol was not applied to subjects with chronic respiratory diseases, it was extended to 15 levels $(1500 \mathrm{~m})$ to minimize the ceiling effect (Dourado et al., 2010). The maximal aerobic speed (MAS) was calculated through ratio distance performed by time final.

\section{PAL - Physical activity level (PAL)}

The PAL assessment was obtained through pedometer model BP 148 TECHLINE®. This estimative is made from vertical oscillation of the body. Each subject did the measurement during three consecutive days on week, and notes step quantity per day before removed the pedometer. The device was setting individually according weight and step length (verified from a measuring tape between right calcaneus and left calcaneus of the subject).

\section{$H R V_{R M S S D}$ - Heart rate variability}

For HRV analyses, the subject received the verbal instruction to not ingested stimulant drinks (coffee, tea or soda) and/or alcohol drink, besides no practice vigorous physical exercise 48 hours before the test and carry out a light meal at most 4 hours. During data recording the subjects remain in supine position for 10 minutes (Guidelines, 1996). R-R intervals (iR-R) data was recording through textile heart rate belt (THRB) by Firstbeat Sports Software $\AA$. Posteriorly, the iR-R data was exported to portable computer and imported for software Kubios HRV® to analyses (Tarvainen et. al., 2014). The iR-R data were analyzed in timedomain, in the variable root mean square of the successive differences (RMSSD). This metric was chosen as it is more reliable than other HRV indexes (Al Haddad e. al., 2011) and can be obtained during spontaneous breathing (Bloomfield et al., 2017). Due to skewed nature of $\mathrm{HRV}$ recording the RMSSD data were transformed into their natural logarithm (InRMSSD). 


\section{Exercise intensity in postmenopausal women}

\section{Procedures}

The experiment was performed during 4 days. In first day was reserved for read and signed the consent form by subjects, anthropometric measurement, application PRETIE-Q, HRV measurement in rest, incremental shuttle walking test (ISWT), verbal explanation of pedometer. The procedure was performed exactly in this temporal order.

\section{Statistical analyses}

Prior to analysis, all data were log-transformed for analysis to reduce bias arising from non-uniformity error. The normality were verified using the ShapiroWilk. The relation between variables was determined through the Pearson's correlation. The confidence interval $(95 \% \mathrm{CI})$ of the association between variables was calculated. The following criteria were adopted to interpret the magnitude of the correlation $(\mathrm{r}): \leq 0.1$, trivial; > 0.1-0.3, small; >0.3-0.5, moderate; > 0.5-0.7, large; >0.7-0.9, very large; and >0.9-1.0, almost perfect (Hopkins et. al., 2009). Stepwise multiple linear regression models were used to MAS, PAL and HRVRMSSD that have best explained the preference score. Variables with $\mathrm{F}$ value $<4$ were removed from the model in the backward procedure. All analyses were conducted in SPSS-22.0 software (IBM Corp., Armonk, NY, USA). The adopted significance was P $\leq 0.05$.

\section{RESULTS}

The descriptive data of preference, maximal aerobic speed, physical activity level and heart rate variability are presented in Table 1.

Table 1. Mean \pm standard deviation of the score preference, maximal aerobic speed, physical activity level and heart rate variability.

\begin{tabular}{ccccc}
\hline \multirow{2}{*}{ Variables } & Preference & MAS & PAL & HRVRIISSD \\
& $(\mathrm{AU})$ & $\left(\mathrm{km} \mathrm{h}^{\mathrm{l}}\right)$ & $($ steps $)$ & $\left(\mathrm{ms}^{-1}\right)$ \\
\hline
\end{tabular}

Subjects $(\mathrm{n}=30) \quad 26.23 \pm 6.36 \quad 7.15 \pm 0.93 \quad 9366.37 \pm 3440.79 \quad 31.77 \pm 12.80$

Note. MAS = Maximal Aerobic Speed $; P A L=$ Physical Activity Level; HRV = Heart Rate Variability.
Preference was large correlated with MAS ( $\mathrm{r}=0.63$; 95\% CI: 0.36-0.81), PAL ( $\mathrm{r}=0.57$; 95\% CI: $0.27-$ $0.78)$ and HRVRMSSD ( $\mathrm{r}=0.52 ; 95 \% \mathrm{CI}$ : 0.19-0.74) (Figure 2). Together, MAS, PAL and HRV RMSSD explained $57.5 \%$ of the preference score $(\mathrm{F} 3,26=$ $\left.11.712, \mathrm{r}_{2}=0.574, \mathrm{p}<0.001\right)$. MAS explained $40.4 \%$, PAL $10.7 \%$ and HRVRMSSD represented additional $6.4 \%$. The preference for high intensity was $56,7 \%$ and low intensity $43,3 \%$.
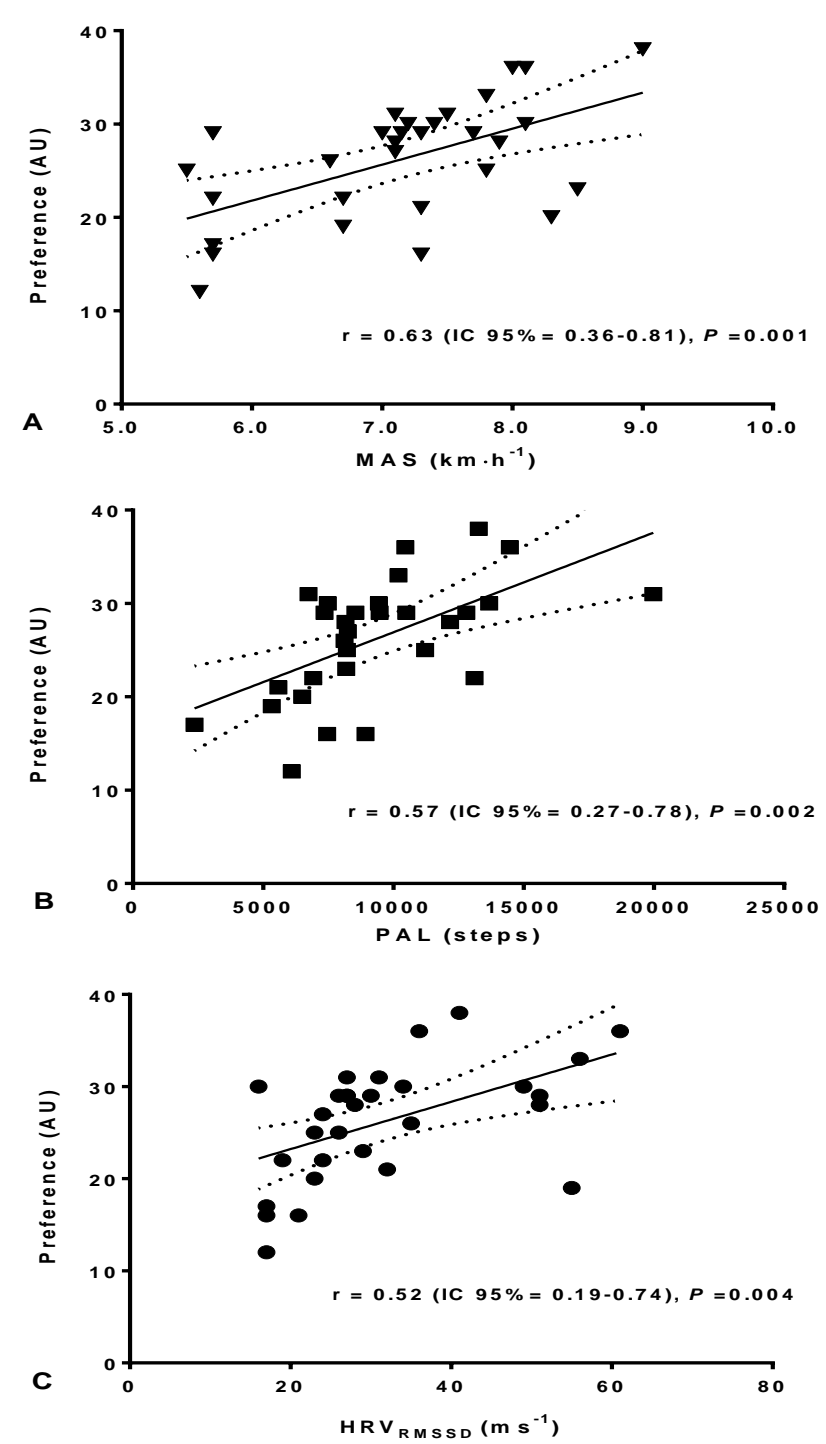

Figure 2. Result of of correlation among preference and MAS (A, black triangle), preference and PAL (B, black square), preference and HRVRMSSD (C, black circle). The dashed line represents the confidence interval at $95 \%$ and the continuous line represents the $V$-slope of the correlation between variables. 


\section{Ornelas, Batista, Meneghel, Dias, Businari, Moreno, \& Lopes, Braz}

\section{DISCUSSION}

The main findings indicate exists a significant correlation between variables MAS, PAL and HRV RMSSD with preference to intensity of exercise, confirming the initial hypothesis of the study. The relationship with the MAS shown higher magnitude of correlation $(r=0.63)$. Already had been described in the literature that aerobic capacity has a relationship with preference to higher intensity of exercise (Garber et al., 2011). This occurs due to subjects with high fitness level had experienced diverse intensity during physical exercise. Cipryan (2018) observed that in equal intensity (\% intensity) subjects well trained showed lowest heart rate than untrained subject. Therefore, high fitness level can represent a preference to high intensity training.

Buchheit (2006) indicated that cardiac-vagal modulation was significantly related to cardiorespiratory fitness $(\mathrm{r}=0.53$; $\mathrm{P}<0.05)$. High values of variable HRV RMSSD reflect a positive health status and cardiovascular effectiveness (Hall et al., 2014). In this case, subjects with higher MAS and HRV have a better quality of life and health, as poor cardiovagal modulation has been associated with sleep disturbance, chronic fatigue, depression, chronic pain and increased risk of cardiovascular disease and mortality (Baynard, et al, 2014; Iellamo et al., 2013). These relationship are important to increase cardiopulmonary performance resulting in a cardioprotective effect, as well as improving physical fitness (Buchheit, 2006). Thus, the findings of this study confirm of observational way that HRV $(r=0.52)$ and MAS $(r=0.63)$ can provide of information the process of choice of the preference by exercise.

It was expected, therefore, greatest PAL and higher parasympathetic modulation in resting also shown significate correlation with preference to intensity of exercise, already both variables have own relationship with aerobic capacity (Batista et al., 2019). Thompson et al. (2004) observed, in middle-age women, negative significant correlation in body composition and usual PAL, being that women with adequate body composition performed more steps per day than women with high body fat percentage and body mass index. (Fiogbé et. al., 2014) observed positive correlation between usual physical activity and parasympathetic modulation. Allied to these findings (Buchheit, 2006; Baynard et al., 2014), the results of the present study support the idea that higher PAL (measured trough pedometer, steps/week) will implicate in individual preference by high intensity exercise, following the same line of theoretical argumentation of the MAS e HRV. As lower physical level, the preference to low intensity during physical exercise will be higher (Garber et al., 2011).

Together, MAS, PAL and HRV RMSSD explained $57.5 \%$ of the preference score. This reinforces the idea that women with high fitness level in postmenopausal phase will prefer higher intensity of exercise. These results can help health professionals in regulation of exercise preference for these populations and, about everything, enhance the adherence and pleasure during the training periodization. In a way, when analyzing one of these variables (MAS or HRV or PAL) health professionals can increase the adherence to physical exercise by the practitioners, in addition to potentiating adaptations for those subjects who prefer high intensity exercise. In this case, preference score may be useful to match the exercise prescription to an individual's exercise disposition.

\section{CONCLUSION}

In conclusion, the results of this study demonstrate that preference of exercise intensity for women in postmenopausal phase is related with aerobic capacity, parasympathetic modulation in resting and physical activity level. Together, these variables can explained $57.5 \%$ of the preference to intensity of the exercise.

\section{PRACTICAL APPLICATION}

The practical application of the results of this study allow to health professional, that prescribe physical exercise, understand that subjects with high aerobic capacity, cardiovagal modulation and usual PAL will have preference for high intensity exercise. In consequence, can increase the adherence to systematic practice of physical exercise. Future studies in others populations should be performed.

\section{ACKNOWLEDGMENTS}

A special thanks to all Participants for their participation. The present study was carried out with the support of CNPq, National Council of Scientific and Technological Development - Brazil. 


\section{Exercise intensity in postmenopausal women}

\section{REFERENCES}

1. Al Haddad, H., Laursen, P. B., Chollet, D., Ahmaidi, S., \& Buchheit, M. (2011). Reliability of resting and postexercise heart rate measures. International Journal of Sports Medicine. https://doi.org/10.1055/s-00311275356

2. Aubert, A., Seps, B., \& Beckers, F. (2003). Heart Rate Variability in Athletes. Sports Medicine, 33(12), 889-919. https://doi.org/10.2165/00007256200333120-00003

3. Batista, D. R., Meneghel, V., Ornelas, F., Moreno, M. A., Lopes, C. R., \& Braz, T. V. (2019). Acute physiological and affective responses in postmenopausal women during prescribed and self-selected aerobic exercise Respuestas fisiológicas y afectivas agudas en mujeres posmenopáusicas durante el ejercicio aeróbico prescrito y auto-seleccionado Resp. Cuadernos de Psicología del Deporte, 19, 28 38.

https://doi.org/https://doi.org/10.6018/cpd.35 9501

4. Baynard, T., Goulopoulou, S., Sosnoff, R. F., Fernhall, B., \& Kanaley, J. A. (2014). Cardiovagal modulation and efficacy of aerobic exercise training in obese individuals. Medicine and Science in Sports and Exercise. https://doi.org/10.1249/MSS.0b013e3182a66 411

5. Billman, G. E. (2011). Heart rate variability A historical perspective. Frontiers in Physiology, 2 NOV, 86. https://doi.org/10.3389/fphys.2011.00086

6. Bloomfield, D. M., Magnano, A., Bigger, J. T., Rivadeneira, H., Parides, M., \& Steinman, R. C. (2017). Comparison of spontaneous vs. metronome-guided breathing on assessment of vagal modulation using RR variability. American Journal of Physiology-Heart and Circulatory Physiology. https://doi.org/10.1152/ajpheart.2001.280.3.h 1145

7. Buchheit, M. (2006). Cardiac parasympathetic regulation: respective associations with cardiorespiratory fitness and training load. AJP: Heart and Circulatory Physiology.

https://doi.org/10.1152/ajpheart.00008.2006
8. Cipryan, L. (2018). The effect of fitness level on cardiac autonomic regulation, IL-6, total antioxidant capacity, and muscle damage responses to a single bout of high-intensity interval training. Journal of Sport and Health Science. https://doi.org/10.1016/j.jshs.2016.11.001

9. Dourado, V. Z., Banov, M. C., Marino, M. C., de Souza, V. L., Antunes, L. C. D. O., \& McBurnie, M. a. (2010). Training \& Testing. A Simple Approach to Assess VT During a Field Walk Test. International Journal of Sports Medicine, 31(10), 698-703. https://doi.org/10.1055/s-0030-1255110

10. Ekkekakis, P. (2017). People have feelings! Exercise psychology in paradigmatic transition. Current Opinion in Psychology, 16, 84-88.

https://doi.org/10.1016/j.copsyc.2017.03.018

11. Ekkekakis, P., Hall, E. E., \& Petruzzello, S. J. (2005). Variation and homogeneity in affective responses to physical activity of varying intensities: An alternative perspective on dose-response based on evolutionary considerations.

https://doi.org/10.1080/02640410400021492

12. Ekkekakis, P., Hall, E. E., \& Petruzzello, S. J. (2008). The relationship between exercise intensity and affective responses demystified: To crack the 40-year-old nut, replace the 40year-old nutcracker! Annals of Behavioral Medicine, 35(2), 136-149. https://doi.org/10.1007/s12160-008-9025-z

13. Ekkekakis, P., Lind, E., Hall, E. E., \& Petruzzello, S. J. (2007). Can self-reported tolerance of exercise intensity play a role in exercise testing? Medicine and Science in Sports and Exercise. https://doi.org/10.1249/mss.0b013e318058a5 ea

14. Fiogbé, E., Ferreira, R., Sindorf, M., Lopes, C., \& Moreno, M. (2014). Função autonômica cardíaca e nível de atividade física de pacientes com doença arterial coronariana. Revista Brasileira de Atividade Física \& Saúde. https://doi.org/10.12820/rbafs.v.19n5p579

15. Focht, B. C., Garver, M. J., Cotter, J. A., Devor, S. T., Lucas, A. R., \& Fairman, C. M. (2015). Affective Responses to Acute 


\section{Ornelas, Batista, Meneghel, Dias, Businari, Moreno, \& Lopes, Braz}

Resistance Exercise Performed at SelfSelected and Imposed Loads in Trained Women. Journal of Strength and Conditioning Research, 29(11), 3067-3074. https://doi.org/10.1519/JSC.00000000000009 85

16. Garber, C. E., Blissmer, B., Deschenes, M. R., Franklin, B. A., Lamonte, M. J., Lee, I. M., Swain, D. P. (2011). Quantity and quality of exercise for developing and maintaining cardiorespiratory, musculoskeletal, and neuromotor fitness in apparently healthy adults: Guidance for prescribing exercise. Medicine and Science in Sports and Exercise, 43(7),

1334-1359. https://doi.org/10.1249/MSS.0b013e318213f efb

17. Guidelines. (1996). Guidelines Heart rate variability. European Heart Journal, 17, 354381. https://doi.org/10.1161/01.CIR.93.5.1043

18. Hall, E. E., Petruzzello, S. J., Ekkekakis, P., Miller, P. C., \& Bixby, W. R. (2014). Role of self-reported individual differences in preference for and tolerance of exercise intensity in fitness testing performance. Journal of Strength and Conditioning Research, 28(9), 2443-2451. https://doi.org/10.1519/JSC.00000000000004 20

19. Hopkins, W. G., Marshall, S. W., Batterham, A. M., \& Hanin, J. (2009). Progressive statistics for studies in sports medicine and exercise science. Medicine and Science in Sports and Exercise. https://doi.org/10.1249/MSS.0b013e31818cb 278

20. Huffman, M. D., Lloyd-Jones, D. M., Ning, H., Labarthe, D. R., Castillo, M. G., O'Flaherty, M., Capewell, S. (2013). Quantifying options for reducing coronary heart disease mortality by 2020 . Circulation. https://doi.org/10.1161/CIRCULATIONAH A.112.000769

21. Iellamo, F., Manzi, V., Caminiti, G., Sposato, B., Massaro, M., Cerrito, A., Volterrani, M. (2013). Dose-response relationship of baroreflex sensitivity and heart rate variability to individually-tailored exercise training in patients with heart failure. International
Journal of Cardiology. https://doi.org/10.1016/j.ijcard.2011.10.082

22. Krinski, K., Machado, D. G. S., Lirani, L. S., DaSilva, S. G., Costa, E. C., Hardcastle, S. J., \& Elsangedy, H. M. (2017). Let's Walk Outdoors! Self-Paced Walking Outdoors Improves Future Intention to Exercise in Women With Obesity. Journal of Sport and Exercise Psychology, 39(2), 145-157. https://doi.org/10.1123/jsep.2016-0220

23. Riebe, D., Franklin, B. A., Thompson, P. D., Garber, C. E., Whitfield, G. P., Magal, M., \& Pescatello, L. S. (2015). Updating ACSM's recommendations for exercise preparticipation health screening. Medicine and Science in Sports and Exercise, 47(11), 2473-2479.

https://doi.org/10.1249/MSS.0000000000000 664

24. Smirmaul, B. P. C., Ekkekakis, P., Teixeira, I. P., Nakamura, P. M., \& Kokubun, E. (2015). Questionário de Preferência e Tolerância da Intensidade de Exercício: versão em português do Brasil. Revista Brasileira de Cineantropometria e Desempenho Humano, 17(5), 550. https://doi.org/10.5007/1980$0037.2015 \mathrm{v} 17 \mathrm{n} 5 \mathrm{p} 550$

25. Tarvainen, M. P., Niskanen, J. P., Lipponen, J. A., Ranta-aho, P. O., \& Karjalainen, P. A. (2014). Kubios HRV - Heart rate variability analysis software. Computer Methods and Programs in Biomedicine. https://doi.org/10.1016/j.cmpb.2013.07.024

26. Thompson, D. L., Rakow, J., \& Perdue, S. M. (2004). Relationship between Accumulated Walking and Body Composition in MiddleAged Women. Medicine and Science in Sports and Exercise, 36(5), 911-914. https://doi.org/10.1249/01.MSS.0000126787. 14165.B3 